\title{
Marsilio Ficino, Neoplatonism, and the Problem of Sex
}

\section{KATHERINE CRAWFORD}

Dans cet essai, nous examinons comment le désir, tel qu'il est présenté dans l'oeuvre de Marsile Ficin, pose des difficultés à ses contemporains surtout en ce qui concerne le désir et la beauté comme moyens d'atteindre le salut. Selon Ficin, le désir homoérotique est central à une compréhension profonde de la nature divine et de la transcendance spirituelle en générale. L'amant et le bien-aimé entrent dans un rapport réciproque (mais inégal) qui est fondé sur une attraction mutuelle et spirituelle. Mais, Ficin constate que l'amant peut se tromper en prenant pour l'amour pur et spirituel un désir physique, sensuel et transgressif. Cet essai présente ces ambiguittés chez Ficin en les appliquant à une lecture de John Ford, Pietro Bembo et Symphorien Champier. Dans ces trois textes, on voit clairement les complexités de la pensée de Ficin en ce qui concerne le désir homoérotique et les égarements de l'amour.

Tn John Ford's 'Tis Pity She's a Whore (printed 1633), Giovanni is in love with his sister, Annabella. Over the objections of the Friar who is also his tutor, Giovanni justifies himself by arguing:

It is a principle (which you have taught When I was yet your scholar) that the frame And composition of the mind doth follow The frame and composition of the body. So where the body's furniture is beauty, The mind's must needs be virtue, which allowed, Virtue itself is reason but refined, And love the quintessence of that. This proves My sister's beauty, being rarely fair, And chiefly in that love, her love to me. If hers to me, then so is mine to her; Since in like causes are effects alike. ${ }^{1}$ 
Linking beauty and virtue, proceeding from the particular form to love as a general category, Giovanni's argument is steeped in Neoplatonic language and logic as it had been revived in Europe by Marsilio Ficino and his followers in the late fifteenth century. But Giovanni takes the notions of love, beauty, and desire in directions that suggest Ficino's efforts to construct a Christianized understanding of Platonic philosophy left open some subversive possibilities. The Friar tries to convince Giovanni to forget his love and allow Annabella to marry. Only by renouncing inappropriate desire will Giovanni be able to save his immortal soul; only by marrying legitimately will Annabella be able to channel any desire she might have into an appropriate venue. In the end, Giovanni is more convinced by his own Neoplatonic logic and the justification it gives for his desires than by the renunciations demanded by the Friar. Ford's play features the conflation of physical desire and notions of transcendent love with disastrous results. Incestuous desire with a consummated sexual component is hardly what Ficino had in mind.

Nor was Ford's the only effort that took Ficino's terms and found that desire and beauty could be moved quickly to highly problematic places. In addition to 'Tis Pity She's a Whore, this essay will analyze different kinds of anxieties around heterosexuality and homoeroticism in Pietro Bembo's Gli Asolani (1505) and Symphorien Champier's Nef des dames (1503). Within Bembo's text, desire between men and women is supposed to be corralled by the operations of love, and yet, disorderly attractions threaten to disrupt social stability. Champier's efforts to articulate transcendent desire keep wandering into thickets of homoerotic attachment and violently destructive desire. In each of these linguistic traditions (English, Italian, and French), Neoplatonic guidelines do not achieve an entirely coherent separation between corporeal and divine love. Despite Ficino's certainty that physical love can and must be put in its proper place, Neoplatonic texts are nonetheless mired in lust and perverse desire.

The literature on Neoplatonism is vast, and sexual issues have not gone entirely unnoticed, but sex was (and for many still is) not really a philosophical matter. Most scholars have been indifferent to its presence. ${ }^{2}$ But what if sex has an intractable centrality in Neoplatonism? This seems apparent in Ficino's work, and in the inability of his interlocutors-Bembo, Champier, and later, Ford are just three of dozens who recur to the same sets of issues - to render sex in innocuous terms. The thematic centrality of desire and beauty, understood as closely identified with sex, resulted in textual entanglements that proved impossible to resolve. ${ }^{3}$ 


\section{Marsilio Ficino and the Problem of Desire}

By the time of Marsilio Ficino (1433-1499), the Christian distinction between sacred (non-corporeal) love and profane (sexual, corporeal) love seemed to correspond to the Platonic notion of love as either philosophical or sensual. Ficino's project of translating and interpreting the Platonic corpus did not, however, fit so neatly. Christians had long regarded sensual love with deep suspicion, marked most conspicuously by the insistence of the Catholic Church that priests reject the physical consummation of love in favour of a conscious, life-long choice of chastity. While the rejection of sexual expression was less dramatic for lay people, ecclesiastical and lay authorities routinely disciplined pleasures of the flesh outside of wedlock. In the Christian context, sexual love was, in most senses, bad. Defined as necessary for the propagation of the species, sex distracted from salvation. The complex of prohibitions on timing, position, and intention during sex built up from the Church Fathers on through the Middle Ages enforced a disciplinary structure to prevent sex from leading the faithful astray. ${ }^{4}$ In contrast, Plato required physical aspects of sensual love in order to produce the move toward philosophical understanding. Of course, part of the idea in Christianity is to overcome corporeal desire on the path to God, which is similar to the Platonic journey from physical attraction to comprehension of the Idea of Beauty. The difference in part is that physical attraction is positively required in Plato's thought, rather than functioning as a negative cipher for Christians - the thing that should be avoided or at least detested relative to the higher virtue embodied in abstinence and chastity. Failing that, Christians could direct desire to "proper" (procreative) ends, but this was always cast as the position of weakness. When Neoplatonic thinkers sought to bring Plato back into the Catholic tradition in the Renaissance, one of the problems they faced was reconciling Plato's utilization of physical desire as an element in his philosophy with the Christian rejection of corporeal pleasure. ${ }^{5}$

The problems associated with sex in the Platonic tradition stem from Ficino's construction of love and desire as salvific elements. ${ }^{6}$ Recurrently in his commentaries on Plato's dialogues but particularly in his Commentary on the Symposium, or De amore (1469), Ficino argued that love and beauty, often in sexualized terms, provided the means to ascend to heaven. At the same time, corporeal desire pulled body and soul downward, and inappropriate desire (variously defined) was often difficult to distinguish from the salvific form. Responses to the issue of sex in Ficino's Neoplatonism were especially complex because he argued for understanding Plato metaphorically. ${ }^{7}$ 
The combination of Christian theology, Platonic allegory, and contemporary understandings of sexualized terminology produced much slippage.

Three intertwined aspects are crucial within Ficino's thought. First, Ficino posits that beauty is crucial to the Platonic ladder of love. Love of beauty leads to contemplation of and union with God. ${ }^{8}$ Ficino echoes Dante's vision of ascending to the comprehension of love through his attachment to Beatrice as articulated in La Vita Nuova. ${ }^{9}$ But where Dante implies an inevitable good in idealized love, as Ficino describes it, salvation is only one possible outcome of the love of beauty. Love can be misguided or wrongly directed, as Ficino admits and his interlocutors abundantly demonstrate. Second, desire in Ficino's philosophy complicates his analysis at several points. Ficino imagines desire in homosexual and homosocial terms, around prevailing notions of male perfection relative to women. ${ }^{10}$ Third and least developed in Ficino's thought is the idea of reciprocity, particularly sexual reciprocity, as a mutual result of desire for beauty. Ficino construed reciprocity in limited terms; later Neoplatonists did not. Many of the problems they encountered appeared as they took a more expansive view of reciprocity.

Following Ficino's lead, writers and thinkers influenced by Neoplatonic ideas worked toward descriptors of interpersonal and sexual relationships that were not about identity in the modern sense, but in which object choice (same sex or opposite sex) did matter. I acknowledge that "heterosexuality" as an identity category was not the terminology of the Renaissance, and the term "homosexual" is of course modern. My use of both terms is always with the awareness of the anachronism. "Homosexual" refers to sex acts (actual or imagined) between persons of the same biological sex; "heterosexual" between persons of different biological sex. I am not using the terms to refer to modern notions of foundational sexual identity. I am arguing that figurations of desire that emanated from Ficino's vision propagated around, rather than resolved, problematic forms of desire and object choice in Neoplatonicallyinflected texts.

In his effort to reconcile Plato with Christianity, Ficino posits an epistemology in which the relationship between soul and body is mediated by the concept of love. In the De amore, Ficino explicates his central notion that love is defined as seeking the divine. Ficino interprets Plato as saying that God, who is unity, extends hierarchically to the multiplicity of physical existence. Within the hierarchy, lesser forms always desire to return to God as the source of existence, and this desire is called love. ${ }^{11}$ The mechanism through which souls seek God is beauty, ${ }^{12}$ and the desire to rise to God through seeking beauty is non-corporeal, non-sexual "Platonic love." Paul Oskar Kristeller credited Ficino with describing "Platonic love" as referring to affection, 
friendship, and non-sexual love with another person. Almost entirely within Ficino's thought, both the lover and the beloved are men. ${ }^{13}$ While Ficino emphasized that non-sexual attraction, called love, is a crucial element leading to understanding of the divine through the contemplation of beauty, his discussions of non-sexual attraction strain to distinguish sexual desire from "pure" attraction. Friendship based on love is central to Ficino's schema, as it was to the Platonic dialogues. However, the desire component in friendship made the seeming simplicity of Platonic love deceptive.

This is largely because Ficino's theology depends on love operating through the auspices of beauty. The analysis of the speech of Agathon in the De amore brings out Ficino's notion that external beauty is a reflection of internal perfection. ${ }^{14}$ God saturated creation with beauty as an expression of divine love. Physical attraction is the result of beauty drawn toward its like within beings created by God's love. Ficino asserts that beauty is not merely external symmetry or proportion; rather, it is timeless, unaffected by age or change, and emphatically not embodied: "No corporeal nature enflames love. Only true beauty retains it. That is, it can have nothing of the corporeal." 15 From this general description, Ficino goes on to contend that real beauty is attracted to the "Angelic Mind," one of the five ontological hypostases. (The others are One, Soul, Quality, and Body.) Michael J. B. Allen has described the origins of the hypostases in Plotinus' work: "[T]he whole philosophy of Plotinus...is a consequence of his dividing reality into a hierarchical series of ontological states where the higher subsumes the lower and the lower emanates from the higher and ultimately from the absolutely prime hypostasis, the transcendent One."16 While Ficino took his time deciding on his five, clearly the notion of the Mind is central to the organization of beauty in the De amore. The process described by Allen is shorthanded by Ficino in sexual terms: "Our soul is engendered in such a condition that, contained in an earthly body, it is inclined to procreate." 17 Having allowed sexual procreation, Ficino emphasizes that the material body is (following Christianized Aristotelian ideas) insignificant compared to the immortal soul. Ficino sums this up by asserting that "...only by divine inspiration can men understand true beauty." 18 Understanding beauty is necessary for the ascent of the soul to the Angelic Mind, and thence to God. The Platonic source for this notion of ascent is often referred to as the "ladder of love," which appears in the Symposium, when Diotima speaks of the love for a beautiful body inspiring love for all bodies. From this abstraction the lover discovers, in hierarchical order, love for souls, laws and customs, all branches of knowledge, the science of beauty, and finally, absolute beauty itself. ${ }^{19}$ For Ficino, salvation is crucial and the ascent is marked by degrees of agency: The body (which can not 
move itself) rises to the soul, which can move itself, but which has an intelligence inferior to that of the Angelic Mind. God, as the highest good, has the potency of cognition and is whole, rather than composite. Only through contemplating the beautiful body is comprehension of God possible. ${ }^{20}$ Beauty is infused by God in all beings, and the quest for beauty as determined by sympathetic attraction is the mechanism for salvation of the soul.

Despite explicitly rejecting physical beauty, Ficino recurs to the idea that finding beauty in the male body is a marker of salvific attraction. Within a cultural context in which unrequited heterosexual love received tremendous play, Ficino emphasized the homoerotic elements: "The role of magic is the attraction of one thing to another because of a certain natural affinity.... From their common paternity is born a love in common, and from love a common attraction.... Even more, someone who is beautiful fascinates us with his eyes. Men delineate and unite with other men by their powers of eloquence and the charms of their songs, as if by incantations." ${ }^{21}$ Drawing at once on Plato's gender politics in his dialogues and on Aristotelian notions that men are inherently more perfect than women, Ficino saw beauty as a matter first and foremost between men.22 This is not surprising, given Plato's homosocial and homoeroticized context, especially as articulated in the Symposium. Greek gender politics around sexuality focused on dyadic age hierarchies between men. Common wisdom regarded women as necessary to procreation but inferior in terms of pleasure, politically irrelevant, and philosophically uninteresting. ${ }^{23}$ At the same time, Ficino draws on the idioms and practices of heterosexual love discourse, especially as developed by Francesco Petrarca and his interlocutors. Petrarchan lyric poetry presumed attraction between lovers who nonetheless never consummate their love. ${ }^{24}$ Unrequited longing created tremendous physical tension.

Aware of the tensions born of desire, Ficino tries to head off concerns about corporeality. After identifying physical attraction as earthly love, Ficino emphasizes that sex between men can be mistaken for true love:

So great is the complete change that occurs in an older man who is inclined toward the likeness of youth that it makes him to want to transfer the whole of his body to him [the young man] and to draw the whole of the youth into himself, so that either the vigorous humor may obtain young arteries, or the younger arteries may get younger blood. Hence they are driven together to do many disgraceful things. For when the genital semen flows down the whole body, they trust that only by ejaculating or receiving this, they can surrender or receive the whole body. ${ }^{25}$

The effects of corporeal desire inspired by beauty can be powerful. Ficino adds to this warning by recalling that a lover, like a pregnant woman (in fact, 
with greater efficacy because the lover is more vehement) will imprint the features of his beloved on himself. This insistence on specifying the functions and power of sexual attraction comes back to masculine homosocial desire: "Women truly easily capture men, and even more those women who bear a masculine character. And even more easily, men catch men, as they are more like men than are women...." 26 While men can be attracted to women (despite the fact that they are lesser beings), beauty is between men.

In addition to the homoeroticism derived from his ancient sources, both Ficino himself and his Florentine context suggest why the homoerotic skein of Neoplatonism was so prominent. Besides his medical training, Ficino was ordained in 1473. Committed to clerical celibacy and inhabiting the homosocial world of learned men, Ficino had little interest in women, whatever his opinion regarding their sexual use value. ${ }^{27}$ According to Michael Rocke, Ficino's Florence had an informal mode of initiating young men into political life through pederastic relationships with older men. ${ }^{28}$ This system was prominent despite its condemnation in Christian sexual ethics. ${ }^{29}$ Since the political structure of Florence limited the rights and privileges of citizenship to established heads of households, men were often forced into a prolonged "adolescence" before marriage. Ties of sociability through sexual relationships reduced the pressure across political generations and established patronage ties and alliances. But secular modalities of sexual sociability were met with persistent religious and cultural strictures condemning sodomy, and male homosexual sodomy especially. Rocke's investigation of the records demonstrates the widespread existence of male homosexual sodomy by virtue of revealing the efforts to control and contain it. Whether beauty was transcendent or merely sexualized was an everyday problem between men in Ficino's milieu. Ficino articulated the idea that particular beauty could move toward the rarified air of divine love and truth. Ficino's corporeal renderings of love were not mere apologia for his personal context or Florentine mores, but they certainly could function that way.

After all, desire could easily disrupt the movement toward God inspired by beauty. Pragmatic efforts to produce a coherent account of desire were enmeshed in the problem of imagining desire in non-sexual terms. Their partial separation in this essay notwithstanding, desire and beauty are inextricably linked in Ficino's formulation. Indeed, Ficino opens the substantive discussion in the De amore by asserting this link. In his opening analysis, Ficino describes the world as formed from Chaos, while God is the author of all things who creates the Angelic Mind, the World Soul, and the World Body. The Mind has an appetite to return to God, and "The first conversion toward God is the birth of Love." 30 The Mind tries to reach God through beauty, which is 
determined by desire: "When we say love, understand this to mean the desire for beauty." 31 Ficino allows that desire for embodied beauty can overwhelm the senses and the intellect. The human will is unreliable at this point. ${ }^{32}$ The pleasures of taste and touch can be so violent that they dislodge the intellect from its proper state. Ficino claims that this is corporeal love. Spiritual love, he insists, not only does not desire, but hates and shuns intemperance as contrary to beauty. Venereal desire can be recognized as corporeal if it leads to ugliness, which Ficino equates with disharmony. Following prevailing medical wisdom that saw the male body threatened by the expulsion of semen, Ficino assumes sex produces disharmony: "Whereby on account of desire for coitus (that is, copulation) and love are shown not only as not the same, but to be contrary." 33 This notion appears elsewhere in Ficino's thought. In Della religione christiana, Ficino emphasized that ejaculation was particularly dangerous for the (male) mind or intellect. ${ }^{34}$ Ficino could tell the difference between transcendent Platonic love and corporeal sexual love, but desire as he described it tended to exceed its boundaries. Despite reassurances that love only seeks proper objects - “... as it hates the ugly, it necessarily flees from foul and indecent things" - the attempt to occlude carnal desire from love is incomplete at best. ${ }^{35}$

Consider Ficino's attempt to bracket sexual desire through reference to the concept of two Venuses and two Cupids - heavenly and "vulgar" or earthly. The heavenly Venus was born of Uranus without a mother, while the earthly was born of Jupiter and Dione. The heavenly Venus is the Mind, and lacks a mother because Ficino, following the Aristotelian medical synthesis, sees maternity as producing only matter, the lower stuff of physical existence. ${ }^{36}$ The earthly Venus is associated with generation and procreation, which Ficino allows is natural. ${ }^{37}$ But he also emphasizes that corporeal distractions are dangerous to those seeking philosophical transcendence:

\footnotetext{
If anyone, being more desiring of generation, forsakes contemplation or values generation with women beyond measure or pursues [it] against the order of nature with men or prefers the form of the body to the beauty of the soul, he certainly abuses the dignity of love. He who correctly uses it, praises the form of the body, but through that, contemplates the higher beauty of the Soul and the Mind and God, and admires and loves that more vehemently. Moreover, he uses the duty of generation and intercourse in so far as the natural order and the civil laws prescribed by the prudent are employed. ${ }^{38}$
}

While Ficino is emphatic about physicality having (and being kept in) its proper place, his formulation acknowledges that it is easy to lose track of what the order of things ought to be. What constitutes proper use, who are "the prudent," and if the rules of the natural order are so transparent, why do 
we need the prescriptions of "the prudent" anyway? The notion of degrees of vehemence implies a spectrum constituted by the lover. And since Ficino has already said that love tends to exceed prudence, will the rules matter at all?

Ficino attempts to solve these problems at several points in his corpus. Ficino's understanding of the immortality of the soul, identified by Charles Trinkaus as crucial to Ficino's positive evaluation of humanity, is one formulation. As Trinkaus argues, Ficino is adamant that the soul strives for God out of a "natural appetite" for truth. The soul's desire for the good is contrasted with bodily appetites, including sexual ones. Ficino distinguishes between soul and body in The Platonic Theology by contending that the soul desires the good at all times, but desires corporeal pleasures only occasionally. Corporeal desires can be curbed; desire for truth cannot. But Ficino admits desire for God is only "much more natural" than the desire for food or sex. The difference is of scale or degree, rather than kind. ${ }^{39}$ Elsewhere, Ficino specifies the differences between heavenly and earthly love, and recurs to corporeal love as oppositional to philosophical love. In his interpretation of the Phaedrean charioteer, for instance, Ficino contends that this opposition is symbolized by the horses that pull the chariot: "Thence Socrates returns to dividing the soul's powers again: he calls reason the charioteer, the twin appetites, the paired horses; and the rational appetite he calls the good horse, the irrational appetite, the bad. The irrational appetite is less bad when it inclines to wrath; worse when it declines to concupiscence." 40 Ficino also adopts the Christian sense of struggle against the sensual as crucial in life: "Our charioteering is said to be difficult because, while the superior horse's motion is towards intelligibles, the inferior's inclines toward sensibles and descends to generation." ${ }^{41}$ Rejecting Christian irascibility concerning pleasures of the flesh, Ficino reads the effort to control desire optimistically. Reason acts to check concupiscence, and crucially, "Love, even when mixed with an inferior appetite, does not cease meanwhile to raise the soul as far as it is able." 42 But the recurrent efforts to contain desire rhetorically indicate that the lines between acceptable and unacceptable forms were difficult to articulate, and the repetition is a sign that Ficino suspected that readers needed special reinforcement on the subject.

Several complications are clustered around procreation. Natural though it is, sexual desire is narcissistic: "This desire, which is innate, for propagating one's own perfection explains the fecundity, latent and implicit, in all things." 43 Ficino sees the value in sexual reproduction as a matter of personal perfection within his theological schema. As Kristeller observes, Ficino locates generation as part of his ontological understanding of inferior substances generated by superior ones and seeking union with them. All 
organisms - and for Ficino, humans are organisms more perfect than other animals - propagate in search of perfection. Ficino vacillated between this idea and the notion that humans reproduce out of fundamental egotism. ${ }^{44}$ The desire for beauty in this dual sense, Ficino asserts, is in all things, including non-corporeal entities such as the arts and the stars. As prophets and priests are supposed to explain which expressions of desire are pleasing to God, Ficino takes on the role of prophet. He designates acceptable sex as a "moderate" (moderatum) thing and its opposite as "intemperate" (intemperata) (p. 163). The latter, of course, ought to be avoided. How exactly one was to recognize when moderation becomes too much of a good thing Ficino leaves unspecified.

Furthermore, male homosociality complicated the premise that desire works toward perfection and similarity. Since transcendent desire in men is inspired by the beauty of other men, separating divine and carnal love is problematic when human procreation is impossible. In a tangle of Aristotelian and Galenic notions of procreation-men are superior in generation, but both biological sexes facilitate reproduction-Ficino constructs his male referential frame for spiritual procreation and love:

Just as the human body is pregnant, according to Plato, so is the soul, and both are stimulated to bringing forth [offspring] by the incitements of love.... Whereas this generative power of the soul, in as much as it lacks cognition, does not discriminate between the sexes. Nature nevertheless incites it toward generation when we judge another body to be beautiful, and it happens often that those who consort with men, in order to sooth the genital part, unite with them. ${ }^{45}$

Ficino then tries to reposition this homosexual desire in the service of what we would recognize as a heterosexual paradigm: "It is proper, however, to notice that the purpose of these excitements is not to throw away, but to strive to fertilize and procreate, and it should be transferred from men toward women." 46 The language contradicts Ficino's often-repeated point that desire for the beautiful man is the first step toward true knowledge. He even added a mild condemnation of male-male desire in the vernacular version. ${ }^{47}$ Desire and beauty had to be channeled so as to avoid "bad" sex, as in the kind that might lead to sin and damnation.

Ficino's struggle on this point is very much about the "necessity" of heterosexuality within his model of reciprocity of desire. Ficino emphasizes that love can be simple (the beloved does not love the lover) or reciprocal (love is the product of two lovers with similar "daemons"). ${ }^{48}$ Reciprocity in love and desire, Ficino contends, keeps the humours in balance and the body healthy. ${ }^{49}$ Mutuality is not easy to achieve, however. Following Plotinus and 
Augustine, Ficino views love in hierarchical terms, with God as its original source. The lover is morally and spiritually superior to the beloved, and so complete reciprocity is not really possible because the partners are unequal. Since the ultimate source of love is God, Ficino posits that the beloved owes love to the lover as a matter of religious duty. This emotional tie is distinct from reciprocity born of affinity and "common attraction," a term that indicates dangerous sexuality for Ficino. ${ }^{50}$ If the lover loses track of the distinction, he leaves himself open for the wrong sort of beauty and desire to take hold. In the worst case, he goes disastrously astray and gets lost in corporeal concupiscence. To avoid going off course, Ficino urges seeking love between two of the most like or proximately equal beings. If desire is properly focused, the lover wants, "to transfer himself into the person he loves," because "he designs and undertakes to become a god." 51 Substantively, this notion of equality means reciprocity is most possible between two men. In the idealized case, Ficino sees reciprocity as a melding or fusion of equals: "As often as two men attach themselves in mutual benevolence, this one lives in that; that one lives in this." 52 Ficino does not say so, but his silence indicates that women cannot, or are unlikely to, accomplish this level of reciprocity. The most that can be expected within the accepted gender hierarchy is that the superior (male) will love more and better than the inferior (female).

For Ficino, heterosexual reciprocity follows the economy of coitus in which men give, women receive, and giving is always better because men do it. ${ }^{53}$ Despite his insistence that reciprocity is intellectual, Ficino admits that misdirection in love resulting in lust and sex is a frequent problem. In the dedication of his Italian translation, Ficino wrote to Bernardo del Nero and Antonio Manetti: "almost all of us love wrongly, and so the more we love, the worse it becomes....We fall into this great error, unfortunately for us, because we boldly start out upon this difficult journey of love before we know its destination or how to travel the perilous path of the journey. The farther we go, the farther we stray." 54 Context again suggests a source for Ficino's hesitation. Michael Rocke posits that notions of reciprocity among men were starting to develop in Renaissance Florence. While sex roles remained highly gendered around the active/passive distinction, the emergence of the idea of pleasure for both partners departed from the ancient model of sodomy as entirely for the pleasure of the active, penetrating partner. This more mutual model was only partial, much contested, and apparently deeply unsettling. ${ }^{55}$ In a sense, the De amore can be seen in part a guide for readers through the thicket created by notions of reciprocity as at once necessary and extremely dangerous. 


\section{Pietro Bembo and Heterosexual Necessity}

Ficino's struggle over the "necessity" of heterosexuality remains truncated, but interlocutors like Pietro Bembo were very much concerned with the problems of heterosexual desire in Neoplatonic terms. On the face of it, Bembo's Gli Asolani foregrounds heterosexual coupling as productive of "proper" desire. The premise of the narrative is that three young men pair up with three women who serve Bembo's kinswoman, Caterina Cornaro, the former Queen of Cyprus. The men have come to Asolo for the wedding of one of the Queen's ladies. The ambiance and the matching sets of men (Perottino, Gismondo, and Lavinello) and women (Berenice, Lisa, and Sabinetta) contribute to the heterosocial climate. Echoes of Boccaccio's Decameron and Petrarchan poetic conceits (characters recite Petrarchan lyrics and sing love songs, especially in the first and second books) recall similar literary settings and their heterosexual erotics. Bembo's dialectical structure-Perottino denounces love, Gismondo praises it excessively, and Lavinello resolves the extremes through recourse to an ascetic hermit's injunctions-offers a naturalized construction to mask the dangers of heterosexual love.

Perottino sets the stage by denouncing love. Because of its physicality, love is always prone to destructive tendencies: "Love, valiant ladies, is not the son of Venus...not [born] of Mars or Mercury or Vulcan himself, or any other god, but in our minds by those base progenitors, but of excessive lasciviousness and sluggish indolence of obscure men and vile parents born as the offspring of sensuality and vices." 56 Love causes nothing but anguish and pain: "And therefore, there is nothing other than the bitterness which I have said is the torment and dolor of the soul...."57 Perottino insists that literary references to love as a god are to teach men that love will destroy all dignity and happiness. He insists bitterly that desire is a disaster, and beauty will always lead men astray.

Where the lover was to be devoted to the beloved regardless of true reciprocity in Ficino's account, Perottino's anger is the result of an unreciprocated love that has left him disillusioned and devastated. Ficino regarded this sort of love as conducive to higher aspirations; Perottino considers it nothing but torment: “...that the man who does not possess that which he desires, many times he suffers from the passions... because the man can not completely enjoy things which are not within him: for things external are always under the arbitrariness of fortune." ${ }^{58}$ Love overwhelms reason, and once caught by the snares of love, the lovers live in perpetual fear of love's end. Perottino casts the dilemma in heterosexual terms, with men afraid of the scorn of women, and even worse, of being cuckolded by them (p. 361). 
The woman is always the source of torment as she causes her male lover's body to waste away, makes him anxious when she is ill, and sparks jealousy in him when she loves someone else. In a pragmatic rendering of Ficino's theory, men (and Perottino means men) can ascend to heaven by their intellect, but earthly attachments to love for women leave men "... in the foul ground, where often by misadventure we are smothered." 59 Perottino's vision of the effects of beauty in a heterosexual context is an utter rejection of Neoplatonic notions.

This is not terribly surprising, given that Perottino is the scorned lover. But heterosexual desire is more generally negative in this part of Bembo's account in a way that echoes traditional Christian condemnations of corporeality: "Desire leads us into disorderly dangers and a thousand miseries. This drives a brother to seek the abominable embraces of a sister whom he loves evilly, a stepmother (to seek those) of her stepson, and some times, that which also to say is serious to me, the father [doing] the same to a virgin daughter: things more monstrous than cruel." While Perottino allows that such possibilities are better left unsaid, recognition of the awful potentialities is important. Otherwise, "[W]e do not know how to save ourselves; or even if we succeed in checking ourselves one time, we, like those who hold it in, give way again and return with greater violence to their own vomit." 60 Damnation is the wages of misdirected heterosexual lust. Whether Bembo finds homosexual desire merely uninteresting or too scandalous to contemplate, heterosexual misrecognition offers dangers aplenty.

Gismondo counters Perottino by offering the conclusion that desire produces reciprocity that is both natural and salvific. The form of desire is heterosexual, as only it creates human civilization and forwards the divine plan. Denying Perottino's link between love and bitterness, Gismondo foregrounds sexual desire in terms of exchanging hearts as an aspect of physical complementarity: "Because if someone loves his lady, he searches for his other half. We are not whole...if we are only male or female."61 Gismondo describes this as the result of natural impulses which are necessary for human existence. Mutual dependence enables happiness, but even more, it permits men and women to fulfill the divine plan.

But even Bembo's most positive character needs help keeping coupled desires properly ordered. In a tautology of heterosexual thinking, all natural desire is reasonable; men and women must come together for the sake of civilization; therefore desire between men and women is reasonable (pp. 419-22). Gismondo's optimistic view of love rests on the faulty premise that "no natural emotion can ever mingle with perturbations." 62 Just how faulty is evident when Gismondo admits that not all men who call themselves lovers are 
telling the truth. More importantly, love is often directed at someone who is beyond the lover's grasp. Gismondo concedes that love often overwhelms the senses, which suggests that desire might not remain within reasonable bounds. His response to this is to advise avoiding "overflowing appetites." 63 That said, Gismondo notes that sometimes excess is normal. Bridegrooms, for instance, can not (and should not) be moderate. Pleasure complicates the preferred formulation of "good" desire as the "natural" fusion of sex and procreation. Heterosexual coitus is natural because it is instrumental, but it is fragile: "That is why if love did not join two separate bodies formed to generate their like, nothing would ever be generated or born." 64 Desire, however natural, might easily miss its mark, which would doom mankind. Accordingly, civilization depends on "the sweet yoke of the wife and the husband coming together with shameful honesty." ${ }^{\prime \prime}$ Bette Talvacchia has explained that onestà in Renaissance Italy was associated with both economic and sexual probity. With respect to courtesans, for instance, "onesto can qualify immorality or lasciviousness rather than cancel it out." 66 Talvacchia does not emphasize it, but the dual association enabled the term to apply to men (for whom economic probity was paramount) and women (who were always subject to sexual suspicion). At once symmetrical and asymmetrical in application by gender, the term allowed imagining complementarity in sexual terms. For Bembo, this means the force of onestà must be contained in marriage, and Gismondo praises the pleasure that comes from loving the opposite sex. The virtues of marriage make men and women together better than either can be alone (pp. 450-2). But in the midst of a paean to beauty, Gismondo gets distracted. He notes that nature often reveals the beautiful body even when it is hidden from view, and shifts the attention of the group onto Sabinetta, "who because of [her youth] and because of the heat of the season had a revealing dress of the thinnest of materials, revealing the shape of two round and firm and unripe breasts through the clinging robe." 67 Reason may save men from destructive desire; onestà in marriage may be natural; but beauty still distracts and leaves reason in disarray.

Given that the dialectic is dysfunctional-Perrotino's part is overly emotional and Gismondo's suffers from failures of logic and reason-the synthesis offered by Lavinello seems especially important. But even here, ambiguities abound. Lavinello's search for answers takes him away from the marriage celebrations and to the home of an ascetic hermit. Lavinello's retreat distances him from heterosexual contact and reinserts a homosocial element into the understanding of love. The conversation between Lavinello and the hermit about desire, especially in editions after the revised one of 1530 , attempt to define proper love as it is directed toward true beauty. ${ }^{68}$ 
Bembo attempts to shore up the notions of the ladder of love and the model of reciprocal dependence embedded in the androgyne myth within the hermit's explanations for why love is properly aimed at immaterial objects. As always, earthly, physical, material desires are contained with tremendous effort. Indeed, the erotics between Lavinello and the hermit ultimately suggest that only isolation can maintain purity of desire.

This is hardly Bembo's stated intention. The narrative introit to the third book stresses that human reason makes truth, "controlling of immoderate desires." 69 Theoretically, reason should operate anywhere, and the first step toward reason is knowing what is true. Lavinello offers that truth lies between Perottino's claim that love is always evil and Gismondo's that it is always good. Lavinello allows that love is desire, and that there are only two forms: those which are natural and those which are the result of human will. Lavinello concedes Gismondo's position that procreation is a natural desire, without which humanity would not survive. Perottino's fulminations get some play in Lavinello's observation that natural desire is simple, but human will is not: It can be deceived or deceiving. The corrective, following Ficino, is that "good" desire is beautiful: "a good love is said to be the same as beauty." 70 However, the senses remain unreliable as indicators of beauty. Lavinello offers three long poems that attempt to identify proper desire by marks of spiritual and physical beauty, but he ends up in a monitory mode, describing transcendent incorporeality and once again evading physical, sexual desire.

Hence, Lavinello retreats into homosocial seclusion. Separate from human contact except for Lavinello's incursion into his space, the hermit presents Lavinello with a reading of desire that parses good and bad forms in terms of denial and inaccessibility. Desire can exist without love, but love can not exist without desire. The key for the hermit is that possession is the end of desire, and the way to maintain love (rather than it becoming mere pleasure) is to never achieve possession of it (pp. 483-4). This harkens back to Petrarch's increasingly distant love for Laura or Dante's for Beatrice. But where Petrarch encouraged obstacles between himself and his love along the ascent, Bembo's hermit systematically removes all physicality. Desire is safe only when alone and without the possibility of achievement. Lavinello's highly tactile presence - the hermit's space and the circumstances of the meeting are lovingly described-underscores the homoerotic connection. Bembo, however, hedges on the question of reciprocity. The text implies that, because of the disparities of age and condition between the subjects, reciprocity is impossible. The hermit can properly love Lavinello because he is unattainable and an impermanent feature within the hermit's secluded 
and inaccessible asceticism. At the same time, the older man initiating the younger man into the ways of beauty replicates the model of homosociality central to Ficino's philosophy.

Not by accident, then, does the hermit emphasize that complete isolation is necessary lest love should follow the senses and go disastrously astray. The good news he offers is that human reason can act as a "bridle," recalling the horse-training imagery of Ficino's Phaedrean charioteer. While man (and, again, it is men because of their superior powers of reason) can sink or rise depending on his self-control, the tendency is to rise because the soul seeks union with God. As Neoplatonic optimism has it, the soul's incorporeal love for God offers protection against misplaced desire. But the soul, imprisoned in the body, may not recall its divine origin. Reason must be trained to recognize only true, internal beauty. ${ }^{71}$ The index of internal beauty is attraction to an immortal object. Physical desire must be denied. The hermit excoriates all things on earth as "base and fetid" ("bassa e fecciosa"), and earthly love is always in the form of unfulfilled desire (pp. 499, 504). Only by renunciation of and separation from worldly contexts can reason have the space to assure this mistake will be avoided. Having insisted on solitude, the hermit's seemingly polite gestures asking Lavinello if he should be on his way take on a different hue. Is Lavinello urged to leave because the possibilities of misdirection remain in play? Hermetic renunciation may not be enough in the presence of an actual object - in this case, a beautiful young man.

Against Ficino's embrace of desire as a necessary element in the process or journey towards salvation, Bembo offers an ascetic formulation to contain the propensity toward carnality that marked sexual desire. However, neither Lavinello nor the hermit, the characters designated to embody this possibility, can maintain ascetic purity in company. Even more, Bembo spends considerable energy corralling homosexual desire and organizing heterosexual interchange toward a salvific end. In Bembo's fictional rendering, only one of three characters is headed for the right path, and to achieve it, he may end up jettisoning the heterosexual contact Bembo constructed in favour of the homoerotics of the hermit. The path remains quite treacherous indeed.

\section{Erotic Stumbling Blocks in Early French Neoplatonism}

The permutations of lust that troubled Bembo's text are reversed in Symphorien Champier's Nefdes dames, which opens with homoerotic attachment and closes with heterosexual union. Champier (1472?-1539), a physician from Lyon, appears to have been the earliest French writer to grapple seriously with Ficino's Neoplatonism. ${ }^{72}$ The Nef des dames is a work of tremendous 
hybridity, but perhaps his intentions were more integrated than it might seem at first. While the parts do not work together harmoniously, Champier can be read as attempting to provide a coherent map to proper desire.

Champier utilizes the medieval love tradition, along with the querelle des femmes, to indicate a practical structure for his culminating Neoplatonic intervention. The effort is ambivalent from the outset, with the unpaginated preface at once praising women as sympathetic and warning them against haughtiness and worldly adornment. In response to misogynous attacks on women, Champier calls those who make such claims "perverted men" (gens pervers). Women are often chaste and pure, he insists, despite famous problem cases like Bathsheba and Dahlila. Men forget "the chastity of Suzanne, the purity of Lucretia... and the valiance of the queen Semiramus" (sigs. bi (v)-ci (r)). ${ }^{73}$ The faults of men are greater, Champier argues, although he is confounded by the question of balance. His thumbnail biographies of chaste, brave, and pious women recuperate feminine virtue, but he is flummoxed by female inferiority prescribed in Genesis (sigs. I ii (r)-I iiii (r)). Women do have their virtues, Champier insists, and they are best expressed in the context of marriage. Accordingly, he devotes his second book to marriage, and attempts to define virtue within its structure of heterosexual desire. His topics are not new-he rehearses Aristotelian ideas about conditions of conceptions and Christian ones about the proper ends of marriage - but he fuses pagan and Christian advice at each stage. He announces that carnality must be controlled for the good of body and soul. Uniting elements from Aristotle and Aquinas, Champier pronounces, "The goods of a woman are beauty and grandeur. And the goods of the soul are temperance [and] love of modesty." He warns that there are two paths: "One is the way from pleasant vice to human sensuality displeasing to God which leads in the end to perdition."74 The other path is marked by the fact that married people have a special place in heaven. Taking on the dual guise of the doctor of the soul and the corporeal physician, Champier offers advice for maintaining a balance between desire and moderation in heterosexual love.

All of this is well and good, but Champier's attempt to organize desire safely within heterosexual marriage is subject to substantial qualifications. For the presentation copy of the first edition (1503), Champier appended a letter in which homoerotic attraction undermines the marital message. ${ }^{75}$ Champier writes to André Briau utilizing several key Neoplatonic concepts articulated by Ficino in the De amore. Champier says he was contemplating Ficino's interpretation of Plato's Symposium and "in the scales of my soul, weighing to whom especially I might direct my love,"76 when Cupid appeared and shot him. Cupid boastfully recounts his triumphs over even the 
king of the gods, and offers Champier a mischievous version of Ficino's typology of love. ${ }^{77}$ After Cupid shoots Briau as well, Champier waxes poetic on the bonds of love between men in the medical profession. The intensity with which Champier describes his relationship and the phallic imagery supplied by Cupid's arrows delivered to both men indicate that Champier understood the implications of Ficino's rendering of transcendent love through male/ male desire. Champier tries to dampen the homoerotics by retreating a bit into the language of procreation: "In fact, the power to generate has the desire to generate beauty, the power of intelligence has the desire to contemplate it." 78 But Champier's intense desire circulating around the figure of Briau nonetheless resonates.

Drawing on Ficino's theories of beauty and desire, the body of Champier's text tries to correct for the imbalance among the types of love in Neoplatonic theory. In so doing, Champier demonstrates how difficult separating good from bad desire can be. On the meaning of beauty, Champier invokes the De amore: "Love is nothing other than the desire for beautiful and honest things.... and love is nothing other than the desire for beauty." 79 Beauty comes in three forms - of body, soul, and voice - and the corporeal forms are dangerous: "The rage and folly of carnal and venereal concupiscence produces prodigality, intemperance, infamy, and vile things." ${ }^{80}$ With Ficino's understanding of beauty in mind, Champier asserts that infamy and ugliness are contrary to beauty, which means that, "This carnal and venereal appetite can not be called love." ${ }^{81}$ How these ideas might actually work in practice is where the difficulties arise. Utilizing familiar stories, Champier attempts to describe proper versions of love between a woman and a man, between a man and a woman, and between two men. Each time, he labours to present strong examples of "good" desire, but his choices are rather strange. His marker of marital desire of a wife for her husband is Artemisia, who proves her love by drinking her deceased husband's ashes and building him a spectacular funerary monument. Her larger governing role, which for many Renaissance commentators was unsettlingly masculine, Champier omits. Heterosexual love is demonstrated by "great anguish" (grand angoisse) and a modified form of postmortem cannibalism (sig. q iii (r)). This is hardly a ringing endorsement for salvific desire.

The reverse situation, of the man who loves a woman, is stranger still. Champier folds an attempt to illustrate the difference between beauty of soul and body into the story of the love of Cymon for Iphigenie, drawn from a Boccaccio tale. ${ }^{82}$ Cymon is "foolish and wild by nature and has rough and ugly speech." He has "the manners more of a beast than of a man." While in the forest, he sees "a beautiful young girl, full of beauty." Cymon is inspired 
to become a "civil man" in order to win her hand. ${ }^{83}$ Champier wants the story to provide ways to read physical beauty as reflective of interior qualities. Cymon is beautiful despite his rude manners and moral defects because he is capable of responding to beauty. But the narrative occludes such a straightforward reading. Although Cymon corrects his faults, he is denied Iphigenie's hand in marriage because she is promised to Passimonde of Rhodes (sigs. q iv (v), r ii (r)- r ii (v)). After Cymon ambushes the ship transporting Iphigenie, a storm traps his ship at Rhodes and he is taken prisoner. Cymon is liberated by a Rhodian magistrate, Lysimacus, who enlists Cymon to prevent the double wedding involving Passimonde and Iphigenie and Lysimacus' beloved, Cassandra, to Passimonde's brother. The complexities of the plot echo the complications of desire, while a sort of repetition compulsion is played out when Cymon kidnaps Iphigenie again. This time, violent abduction is coupled with murder: Cymon kills Passimonde. How transcendent is the beast's love after all? Champier insists on four separate occasions that Cymon's love for Iphigenie's beauty is transformative, asserting finally that Cymon's love was not carnal or venereal. Perhaps, but martial prowess in the form of homicidal violence is the salient marker of the contours of Cymon's desire.

Champier's model for male/male love - the friendship between the Greek Gisippus and the Roman Titus - seems faithful to Ficino's homosocial premises, but rests finally on heterosexual mediation. Educated together at Athens, the men become close companions. Gisippus is betrothed to Sophronia, but Titus falls in love with her. Torn between his devotion to Gisippus and his desire for Sophronia, Titus wastes away. After Titus confesses his love, Gisippus convinces him to take his place in the marriage bed because, "he would rather lose his wife than his friend, because it is easier to find another wife, but not a friend." 84 When Titus is called back to Rome, he takes Sophronia (who is shocked to discover she has been sleeping with Titus), while Gisippus remains in Athens. Disgraced and exiled soon afterwards, Gisippus goes to Rome, but is not recognized by Titus on account of his ragged condition. Gisippus takes refuge in a cave, where he is soon joined by a pair of robbers using the cave as a hideout. The bandits quarrel, one is killed, and the Praetorian Guard comes to investigate. Gisippus, having resolved to die, confesses to the murder knowing he will be put to death. Titus happens to be in the court for the sentencing, and this time, recognizes his old friend. Titus tells the magistrate he was the murderer in order to save Gisippus. The power of friendship is such that the actual killer feels remorse and confesses as well. All three are sent to Octavian, who exonerates Titus and Gisippus and pardons the actual killer for good measure. Our heroes are fully reunited when Gisippus marries Titus's sister, and the two couples form a joint household. 
Champier dampens the immediacy of the homoerotic connection by mediating it through Sophronia and Titus's sister. The sexual link through the wives is a result of the profound intimacy between the men. Male intimacy is constructed by deceiving Sophronia, and by regarding her as interchangeable and expendable. Moreover, while the joint household was not uncommon in early modern Europe, it was uncomfortably close to incest by contemporary legal standards. Among the unions prohibited under incest statutes were those with collateral relatives. ${ }^{85}$ Champier's male-male love casts wives as placeholders and creates illicit, carnal, corporeal connections between men at the expense of society.

Champier's recurrent concern is the misrecognition of desire as a matter of proper - that is, heterosexual - channelling of it. He warns against "carnal concupiscence, which is a kind of derangement and fury." 86 As part of his larger pedagogical program, Champier warns that women especially are prone to "false love" (faulse amour). His example is Lucilia, daughter of Apollo. Beautiful in appearance, she is left to her own devices and "becomes lascivious" (devint lascive). Apollo initially rejects her pleas, but he finally relents and saves her from her "worldly voluptuousness" (volupté mondaine). The gendering of this tale enables Champier to exhort his audience to fulfill gendered expectations: "Oh Ladies, you should be in love with true love and not fear what Plato said when he said that those who love are dead in themselves, and live in another, because he lives in the thing he loves...Oh, men, be virile. Oh ladies, be virtuous, prudent, and chaste...." 87 The qualities - female prudence and modesty and male virility - determine the contours of proper desire. Despite all the narrative slippages revealed in Champier's illustrations, gendered virtues are situated textually as mutually sustaining around heterosexual dyads. Champier's efforts to elide the homoerotics, the displacements around beauty, and the strange manifestations of desire invite us to return to our earlier questions: What constitutes proper use? Who are "the prudent"? The difficulties in Champier's text around these questions are symptomatic of the lack of clarity concerning whether desire is properly transcendent or improperly carnal.

\section{John Ford and the Return of the Unrepressed}

Champier's encounters with misdirected desire are relatively benign compared to what John Ford describes. Misrecognition saturates 'Tis Pity She's a Whore. Hippolita's desire for Soranzo leads (she believes) to her husband's death, at which point she is spurned by her lover. She trusts Vasques when she seeks to avenge her lost honour by killing Soranzo, only to be betrayed by 
Vasques as well. For his part, Soranzo ardently woos Annabella and marries her, believing her chaste - only to discover she is pregnant by her brother. Grimaldi's desire for revenge on Soranzo leads to the accidental murder of Bergetto. Even Richardetto, Hippolita's husband in disguise, does not entirely escape the disasters of desire: seeking revenge on Soranzo, the poison he provides to that end kills Hippolita instead. Each case can be seen as a lesson in improper desire, with love and lust figuring in every instance.

All of these examples pale next to Giovanni's love for his sister. This mistaken desire produces utter disaster. Giovanni's expressions of love include blazon-like catalogues of Annabella's appearance and standard love formulae praising her virtues and beauty. Giovanni tells the Friar:

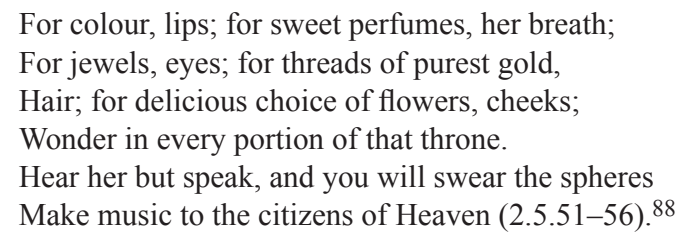

At once sensitive to his interlocutor and completely tone deaf to his own words, Giovanni alludes to physical desire, but breaks off rather than offend the Friar. Giovanni evidently missed the part in Neoplatonic theory in which the primary indicator of bad desire is physicality. Love blinds both brother and sister to the danger of mistaken desire because of Giovanni's ability to cast it in transcendent terms. Consummation takes two, and Annabella plays her part as well. She catches sight of a man (Giovanni, of course) from a distance, describing him as "some celestial creature" with a "blessèd shape" (1.2.121-22). The language draws on the Neoplatonic notion of external beauty as indicative of a beautiful soul. Having failed to eradicate thoughts of his sister from his mind, Giovanni confesses to her, but circuitously. He opens, "I think you love me sister," and draws from her that this is more than the usual love between siblings (1.2.178). Giovanni's roundabout confession stems from his fear that Annabella will be horrified by his love. So much for prudence. Giovanni in this moment knows his desire is wrong, but allows it to overwhelm his reason anyway. Annabella, although she can (by the logic of the time) be seen as less culpable because of her inferior feminine powers of reasoning, overcomes prudence as well. She reassures the nervous Giovanni, "Live, thou has won/The field..." (1.2.234-5). Once coupled, the siblings swear on their mother's grave not to betray each other, and seal their mutual promise with a kiss. If they were not siblings, in early modern contexts, Giovanni and Annabella did what ecclesiastical law required to be 
considered married: they have consented to share each other body and soul, and they have ritually sealed the promise before God. ${ }^{89}$ Physical consummation takes place almost immediately, another gesture to the laws around marital legitimacy. Despite the formal aspects of the union and the Neoplatonic language around it, the aftermath reveals the perversity of physicality. The couple emerges blissfully after sex discussing the loss of her maidenhead and exclaiming that their hearts are conjoined by desire (2.1.1-12).${ }^{90}$ When asked by Annabella's servant, Putana, about the experience, Annabella indicates that desire leads to heaven: "O Guardian, what a paradise of joy/Have I passed over!" (2.1.39-40). The logic of Neoplatonism produces seductions of the flesh, death, and damnation, and all far more readily than salvation.

The complications of Ford's theatrical context bring his thematic choices back to the homoerotic center of Neoplatonism. When the play was first performed, all the roles were played by men. In her discussion of sexual ambiguity in the Elizabethan theatre, Lisa Jardine comments, "...the boy player is liable to be regarded with erotic interest which hovers somewhere between the heterosexual and the homosexual around his female attire." 91 Annabella played by a boy actor in a sense fulfills Ficino's model of male/male attraction. The theatrical context provides a cover, but one that was deliberately a matter for the audience to manipulate. Nor is this is the only time that incestuous sibling desire appears on the English stage. The conceit of twins of the opposite sex (sometimes identical as in Shakespeare's Twelth Night; sometimes just paired as in Webster's The Duchess of Malfi) draws dramatic power both from the recognition of the boy actor cross-dressing and from the denial of the homoeroticism inherent in the all-male cast. Desire is not just allowed, but made to flow in multiple directions - and most of them do not lead toward Ficino's vision of salvific love.

In Ford's play, the tragic ending emerges in part because the characters diverge in their understandings of transcendent love. Annabella starts to feel guilty and reconsiders the logic of her love for Giovanni. She laments that beauty has deceived her: "Beauty that clothes the outside of the face/Is cursèd if it be not clothed with grace" (5.1.12-13). For Giovanni, love, including its sexual expression, remains constant even after Annabella marries. He expected it to change and "die," but instead, "She is still one to me, and every kiss/As sweet and as delicious as the first" (5.3.8-9). The persistence of physical attraction for Giovanni confirms his belief in the transcendent quality of his love. His insistence on retaining it leads him to kill Annabella, whose growing sense of guilt about her relationship with Giovanni complicates the reading of her death. She is surprised by Giovanni's murderous intent, but submits willingly when he stabs her. For the audience, the vis- 
ceral image of love gone radically astray is Annabella's heart brandished on Giovanni's knife.

Wrong desire only becomes obvious when it is exposed. As Ford, Bembo, and Champier in different ways indicate, the danger is that the damage will already be done before it is recognized. In a sense, these texts reveal concerns about Neoplatonic ideas in very practical terms. Their pedagogical impulse is not merely a reworking of primordial Christian anxiety about sex. Ficino's Neoplatonism challenged Catholic assumptions about the sinfulness of most corporeal desire, but raised new problems that required explication. Getting beauty and desire "right" featured prominently first in Ficino's Neoplatonism and then in texts that relied on its philosophical tenets for greater understanding of that human condition called love. Ficino's interlocutors tried to offer guidance to ensure that sexual desire did not overwhelm reason; to ensure that desire led to salvation. But even as Neoplatonic texts strained toward normative descriptors of the sexual, they inscribed the disruptive tendencies of homoerotic attraction and heterosexual misrecognition that resulted from stray desire and misleading beauty.

\section{Vanderbilt University}

\section{Notes}

1. John Ford, 'Tis Pity She's A Whore and Other Plays, ed. Marion Lomax (Oxford: Oxford University Press, 1995), pp. 2, 5, 12-26. All citations are from this edition.

2. There are exceptions, such as James Hankins, Plato in the Italian Renaissance, 2 vols. (Leiden and New York: Brill, 1990) which traces censorship and bowdlerizing in early translations and interpretations of Plato, particularly around questions of homosexuality. John Charles Nelson, Renaissance Theory of Love: The Context of Giordano Bruno's "Eroici furori" (New York: Columbia University Press, 1958) notes overlaps between sacred and profane love in several skeins of Neoplatonism. Some art historians, on encountering sexualized, usually homoerotic images in the works of artists who were influenced by Neoplatonic ideas, regarded sex as thematically central. See especially Erwin Panofsky, Studies in Iconology: Humanistic Themes In the Art of the Renaissance (New York: Icon, 1972) and Edgar Wind, Pagan Mysteries in the Renaissance (London: Faber \& Faber, 1958); Edgar Wind, "Platonic Justice, Designed by Raphael," Journal of the Warburg Institute 1 (1937), pp. 69-70. Panofsky came close to regarding the failure of Michelangelo's Neoplatonic funerary programs not merely as a problem of collapsed patronage, but also as a result of the artist's inability to fuse the sexualized elements with the claims for transcendence in Platonic philosophy. See pp. 171-230 of Studies in Iconology. For a comprehensive bibliography on Neoplatonism in the Renaissance, see Paul O. Kristeller, Ficino and his Work after Five Hundred Years (Florence: L.S. Olschki, 1987), pp. 36-66 for secondary materials, and Michael J. B. Allen and Valery Rees, ed. Marsilio Ficino: His Theology, His Philosophy, His Legacy (Leiden: Brill, 2002), pp. 443-66. 
3. These issues occur in a wide range of Neoplatonic texts besides the ones considered here. Among the authors who struggle with sex and sexual desire are Mario Equicola, Giovanni Pico Della Mirandola, Leone Ebreo, Baldassare Castiglione, Louys Le Roy, Guillaume des Periers, Antoine Héroët, Gilles Corrozet, Marguerite de Navarre, Guy Le Fèvre de la Boderie, Pontus de Tyard, Maurice Scève, Joachim du Bellay, Charles de Sainte-Marthe, Philippe Desportes, and Pierre de Ronsard. This is a very partial list, but it includes Catholics, Protestants, poets, philosophers, political theorists, authors of narrative fiction, and several language traditions. The principle illustrations in this essay were selected for geographic range and because all had significant influence on their respective contexts.

4. On this structure, see for instance Pierre J. Payer, Sex and the Penitentials: The Development of a Sexual Code, 550-1150 (Toronto: University of Toronto Press, 1984).

5. For convenience, I use the term Neoplatonism, although Paul O. Kristeller reminds us that it was not a unified philosophy. See Kristeller's "The Scholastic Background of Marsilio Ficino: With an Edition of Unpublished Texts," Studies in Renaissance Thought and Letters (Rome: Edizioni di storia e letteratura, 1956), pp. 35-97. There is some debate about Ficino's Platonic borrowings relative to the influences of Plotinus and Avicenna. Regarding the former, see Laura Westra, "Love and Beauty in Ficino and Plotinus," Ficino and Renaissance Neoplatonism, eds. Konrad Eisenbichler and Olga Zorzi Pugliese (Toronto: Dovehouse, 1986), pp. 175-87. Westra highlights divergent understandings of love and beauty, emphasizing Ficino's negative perspective on corporeality compared to that of Plotinus. She regards beauty as comparatively insignificant in Ficino's thought (see p. 178), but her reading is based on the Theologiae Platonicae. Beauty is more prominent in the De amore. On Ficino and Avicenna, see Giuseppe Saitta, Il pensiero Italiano Nell'Umanismo e Nel Rinascimento: Vol. 1, L'Umanismo (Bologna: Cesare Zuffi, 1949), pp. 509-75, esp. 510 and 537. When I speak of Neoplatonism, I am referring to Ficino's synthesis. While I suspect that some of the slippages below can be traced to the various influences Ficino incorporated, I leave that line of inquiry to others.

6. On Ficino and love, see for instance Jean Festugière, La Philosophie de l'amour de Marsile Ficin et son influence sur la littérature française au XVIe siècle (Paris: Librairie Philosophique J. Vrin, 1941). A few commentators have drawn out the sexual aspects of love discourse. See especially Armando Maggi, "On Kissing and Sighing: Renaissance Homoerotic Love from Ficino's De Amore and Sopre Lo Amore to Cesare Trevisani's L'impresa (1569)" Journal of Homosexuality 49/3-4 (2005), pp. 315-39, and Hiroshi Hirai, "Concepts of Seeds and Nature in the Work of Marsilio Ficino," Allen and Rees, Marsilio Ficino, pp. 257-84. Maggi traces the homoerotic structure of the De amore and iterations of homoeroticism in later texts; Hirai discusses Ficino's concept of "seminal" and related ideas in his corpus.

7. Marsilio Ficino, Theologia Platonica de immortalite animorum (1469-74). For a brief discussion of the textual history, see Platonic Theology, trans. Michael J. B. Allen and ed. James Hankins and William Bowen, 6 vols. (Cambridge, MA.: Harvard University Press, 2001-2006), vol. 1, pp. vii-xvii and 315. On Ficino's efforts to produce a theological 
system, see Jörg Lauster, "Marsilio Ficino as a Christian Thinker: Theological Aspects of his Platonism," Allen and Rees, Marsilio Ficino, pp. 45-69.

8. William R. Bowen, "Love, The Master of all the Arts: Marsilio Ficino on Love and Music," in Love and Death in the Renaissance, ed. Kenneth R. Bartlett, Konrad Eisenbichler, and Janice Liedl (Ottawa: Dovehouse, 1991), pp. 51-60. Bowen argues that the concept of harmonia (defined as "the proper arrangement of consecutive sounds, or, more abstractly, to the scale structure underlying true melody...") is crucial to understanding Ficino's notion of love in his cosmology. Seeking beauty is disruptive of universal hierarchy, but harmonia provides unity. See esp. pp. 51-2.

9. Dante Alighieri, Vita Nuova. Italian Text with Facing English Translation, trans. Dino S. Cervigni and Edward Vasta (Notre Dame and London: University of Notre Dame Press, 1995).

10. On the homosocial aspect elsewhere in Ficino's work, see Marsilio Ficino, Three Books on Life, ed. and trans. Carol V. Kaske and John R. Clark (Binghamton: Renaissance Society of America, 1989), pp. 29-30.

11. Marsilio Ficino, Commentaire sur le banquet de Platon, ed. and trans. Raymond Marcel (Paris: Les belles lettres, 1956) [Hereafter De amore], pp. 146-52. Marcel reproduced the Latin text from Ficino's autograph manuscript (Vatican Latin 7.705). The original date is 1469, although it was not published until 1484. On love as desire for unity with God, see also Marsilio Ficino, The Letters of Marsilio Ficino, trans. London School of Economic Science, 6 vols. (New York: Schocken Books, 1981, 1985), vol. 1, p. 37 (Ficino to Michele Mercati).

12. On beauty in Ficino's corpus, see especially Michael J. B. Allen, The Platonism of Marsilio Ficino: A Study of the Phaedrus Commentary, Its Sources and Genesis (Berkeley: University of California Press, 1984), pp. 185-203, esp. 188. Allen also identified Ficino's primary speaker in the De amore, Giovanni Calavcanti, with Phaedrus, the protagonist of Plato's dialogue of that name (which is the other lengthy discussion of love in Plato's dialogues) and a prominent actor in the Symposium. See "Cosmogony and Love: The Role of Phaedrus in Ficino's Symposium Commentary," Journal of Medieval and Renaissance Studies 10/2 (1980), pp. 131-53.

13. Ficino, Letters, vol. 5, pp. 81-3 (Ficino to Alammano Donati). Paul O. Kristeller, The Philosophy of Marsilio Ficino, trans. Virginia Conant (New York: Columbia University Press, 1943), pp. 285-8 identifies this letter as the source of the notion of Platonic love (amore Platonico): "...we begin meanwhile to love each other, so that apparently we have realized and perfected in ourselves that Idea of true love which Plato formulates in his work. From this Platonic love therefore a Platonic friendship arises..." (p. 286).

14. See Ficino, De amore, p. 178: "Interiorem bonitatem, exteriorem pulchritudinem dicimus." See also pp. 188-90 for the same concept. Ficino vacillated on the question of correspondence between physical and spiritual beauty. See for instance Letters, vol. 2, p. 74 (Ficino to Giovanni Cavalcanti) and vol. 4, p. 67 (Ficino to Friends), which assert beauty of the body reflects beauty of the soul, while Letters, vol. 1, pp. 44-5 (Ficino to Peregrino Agli) warns that beauty of the body is source of lust. The coherence between internal 
and external beauty was much disputed in art theory. See for instance the concerns in Gian Paolo Lomazzo, Trattato dell'arte della pittura, scoltura et architettura [1584] in Scritti sulle arti, ed. Roberto Paolo Ciardi, 2 vols. (Florence: Centro Di, 1974), vol. 2, pp. 113-53 and in his Idea del Tempio della Pittura [1590] in Scritti sulle arti, vol. 1, pp. 292-8, 308-10. See also Lodovico Dolce, Dialogo della pittura intitolato l'Aretino [1557] in Scritti d'arte del Cinquecento, ed. Paola Barocchi, 3 vols. (Milan and Naples: Riccardo Ricciardi, 1973), vol. 1, pp. 792-4. On Neoplatonic notions in Renaissance art, see especially André Chastel, Marsile Ficin et l'art (Geneva: Droz, 1975), and Francis Ames-Lewis, "Neoplatonism and the Visual Arts at the Time of Marsilio Ficino," Allen and Rees, Marsilio Ficino, pp. 327-38. See also Panofsky, Iconology, and Wind, Pagan Mysteries.

15. Ficino, De amore, p. 184: “Amor nullo impletur aspectu corporis vel amplexu. Nullam igitur naturam corporis ardet, pulchritudinem certe sectatur. Quo fit ut ea corporeum aliquid esse non posit." All translations are mine unless otherwise indicated, but I have consulted both Marcel's French translation and Sears Jayne's English translation, Commentary on Plato's Symposium, trans. Sears Jayne (Dallas: Spring Publications, 1978), and utilized the Dictionnaire Historique de la langue française, ed. Alain Rey et. al., 3 vols. (Paris: Dictionnaires Le Robert, 1998) in order to translate the Latin according to sixteenth century habits of vocabulary and syntax, although my translations are utterly utilitarian.

16. Michael J. B. Allen, "Ficino's Theory of the Five Substances and the Neoplatonists' Parmenides," Journal of Medieval and Renaissance Studies 12 (1982), pp. 19-44. See p. 19. Allen corrects Kristeller's reading of the hypostases in Ficino's thought.

17. Ficino, De amore, p. 185: "Sed enim animus noster, ea conditione genitus ut terreno corpore circumdetur, ad officium generandi declinat." On the Angelic Mind and its relationship to Venus in Ficino's thought, see Clement Salaman, "Echoes of Egypt in Hermes and Ficino," Allen and Rees, Marsilio Ficino, pp. 115-35, esp. 123-5.

18. P. 199: “...ut ostenderet sola divinitatis inspiratione quid vera pulchritudo sit...." See p. 188 on the preeminence of the soul.

19. Plato, Symposium, trans. Christopher Gill (London: Penguin, 1999), 210a-212a. There is a different version of the ladder of love in Giovanni Pico della Mirandola, Commento a una canzone del Benivieni, which was first published in 1519, but probably composed around 1486. On the context of its genesis and for an accessible modern edition, see Giovanni Pico della Mirandola, De hominis dignitate, Heptaplus, De ente et uno, ed. Eugenio Garin (Florence: Vallecchi Editore, 1942), pp. 10-11, 443-581. After the love for one beautiful body, Pico contends that the next step involves the lover making the image of love more perfect and spiritual. Then the soul distinguishes universal beauty from sensory images of love. Awareness of the power of abstraction and of ideal beauty follow. From there, the soul rises to approach ideal beauty intellectually, and then to merge with the Angelic Mind to achieve complete awareness. Finally, and only with God's help, the lover attains union with God. This culminating step is not available to mortal beings, 
according to Pico, a difference from Ficino's understanding of love as offering the ability to achieve salvation.

20. Ficino, De amore, p. 230-9.

21. Pp. 220-1: "Magice opus est attractio rei unius ab alia ex quadam cognatione nature.... Ex communi cognatione communis innascitur amor, ex amore, communis attractio.... Quin etiam formosus quisque teneris nos fascinat oculis. Viri eos eloquentie viribus et carminum modulis, quasi quibusdam, incantantionibus, deliniunt sibique conciliant." See also Ficino, Letters, vol. 4, pp. 66-7 (Ficino to Friends), in which Ficino slides from a female to a male object of beauty, and then to the seduction of the beautiful male body.

22. On the Aristotelian aspect, consult Ian Maclean, The Renaissance Notion of Woman: A Study in the Fortunes of Scholasticism and Medical Science in European Intellectual Life (Cambridge: Cambridge University Press, 1980), pp. 9-15.

23. See for example K. D. Dover, Greek Homosexuality (New York: MJF Books, 1978); Daniel H. Garrison, Sexual Culture in Ancient Greece (Norman: University of Oklahoma Press, 2000), esp. pp. 153-75. For the persistence and evolution of male homosexual relations in Roman antiquity, see Craig A. Williams, Roman Homosexuality: Ideologies of Masculinity in Classical Antiquity (Oxford: Oxford University Press, 1999). Williams lucidly delineates differences between Greek and Roman sexual mores regarding male homosexual behavior.

24. The literature on Petrarchan love is vast, but for particularly cogent accounts of the cultural effects of Petrarchan poetry, see Roland Greene, Unrequited Conquests: Love and Empire in the Colonial Americas (Chicago and London: University of Chicago, 1999) and François Lecercle, La Chimère de Zeuxis: Portrait poétique et portrait peint en France et en Italie à la Renaissance (Tübingen: Gunter Narr Verlag, 1987).

25. Ficino, De amore, p. 251: "Tanta permutatio senioris hominis vergens ad iunioris similitudinem facit ut iste totum sui corpus in illum transferre et totum illius in se transfundere studeat, ut vel recens humor vasa recentia, vel vasa teneriora teneriorem consequantur humorem. Hinc multa inter se turpissime facere compelluntur. Cum enim genitale semen a toto corpore defluat, solo huius iactu vel tractu totum corpus tradere se posse confidunt et totum accipere."

26. P. 253: "Femine profecto viros facile capiunt, facilius autem ille que masculam quandam indolem pre se ferunt. Et tanto facilius masculi quanto similores sunt viris quam femine...." On the importance of likeness to love, see also Letters, 1:197 (Ficino to Amerigo Corsini).

27. This is not surprising given the gender dynamics in Renaissance Florence. See for instance Michael Rocke, "Gender and Sexual Culture in Renaissance Italy," Judith C. Brown and Robert C. Davis, ed. Gender and Society in Renaissance Italy (London and New York: Longman, 1998), pp. 150-70. See Anthony Grafton and Lisa Jardin, "Women Humanists: Education for What?" From Humanism to the Humanities: The Institutionalizing of the Liberal Arts in Fifteenth and Sixteenth-Century Europe (Cambridge MA.: 
Harvard University Press, 1986), pp. 29-57 for the homosocial environment in which humanistic studies took place.

28. Michael Rocke, Forbidden Friendships: Homosexuality and Male Culture in Renaissance Florence (Oxford and New York: Oxford University Press, 1996), passim.

29. See Mark D. Jordan, The Invention of Sodomy in Christian Theology (Chicago: University of Chicago, 1997) regarding the construction of male homosexual sodomy as unacceptable in Medieval theology.

30. Ficino, De amore, p. 140: "Primam ipsius in deum conversionem, amoris ortum."

31. P. 142: "Cum amorem dicimus, pulchritudinis desiderium intelligite."

32. Ficino's account of the Aristophanes myth includes both the idea that the will is operative and that it is not. See De amore, pp. 167-8. For more on Ficino's conception of the will, see Tamara Albertini, "Intellect and Will in Marsilio Ficino: Two Correlatives of a Renaissance Concept of mind," in Allen and Rees, Marsilio Ficino, pp. 203-25, which argues for Ficino's innovative solution to the will/intellect problem. See also Kristeller, Philosophy, pp. 256-88. Robert V. Merrill, "The Pléiade and the Androgyne," Comparative Literature 1 (1949), pp. 97-112, see esp. p.109 for the argument that free will is impossible in Plato's philosophy because love is determined by God, but this is a bit reductive.

33. Ficino, De amore, p. 143: “Quapropter libido conitus, id est, coeundi, et amor, non modo non iidem [idem?] motus sed et contrarii esse monstrantur." Marcel identified the manuscript variant iidem/idem. I have added punctuation for clarity. See Ficino, Letters, vol. 1, p. 43 on the body depressed by corporeal desire.

34. Marsilio Ficino, De religione christiana (Florence: Giunti, 1563), p. 16.

35. Ficino, De amore, p. 143: “...qui odit deformia, necessario turpia obscenaque fugit."

36. On Ficino's cosmology, see especially Allen, Platonism (1984), pp. 113-64. I have chosen the term "earthly" to provide some distance from the non-pejorative word, "volgare," but the negative connotations of "vulgar" apply relative to the earthly Venus.

37. Maggi, "On Kissing and Sighing," argues that Ficino sees love between a man and a woman as natural, but love between two men as "more natural" (p. 322). I am suggesting that natural (read: homoerotic) and natural (read: procreative) are only sometimes defined by the same spiritual imperatives.

38. Ficino, De amore, p. 155: "Si quis generationis avidior contemplationem deserat aut generationem preter [sic: praeter] modum cum feminis vel contra nature ordinem cum masculis prosequatur aut formam corporis pulchritudini animi preferat, is utique dignitate amoris abutitur....Quo qui recte utitur, corporis quidem formam laudat, sed per illam, excellentiorem animi mentisque et dei spetiem cogitat eamque vehementius ammiratur et amat. Generationis autem et congressus offico eatenus utitur, quatenus naturalis ordo legesque civiles a prudentibus statute prescribunt." I have chosen the term "generation," rather than "procreation," as it was the term utilized in Ficino's context. 
Katherine Crawford / Neoplatonsism and the Problem of Sex /31

39. Marsilio Ficino, Théologie platonicienne, ed. and trans. Raymond Marcel, 3 vols. (Paris: Les Belles Lettres, 1964-70), vol. 2, p. 253: "Quanto igitur naturalior est veri bonique quam cibi coitusque cupiditas...." See Charles Trinkaus, In Our Image and Likeness: Humanity and Divinity in Italian Humanist Thought, 2 vols. (Chicago: University of Chicago Press, 1970), vol. 2, pp. 461-505, esp. 488-9 for discussion of Ficino. Trinkaus notes that Ficino identifies human beings in terms of a similar scale of difference relative to animals. See p. 497.

40. Michael J. B. Allen, Marsilio Ficino and the Phaedran Charioteer (Berkeley: University of California Press, 1981), p. 78. (The translations from this text are all Allen's). Allen notes this sentence does not appear in several early versions of the text, but it does appear in Prohemum Marsilii Ficini florentini in commentaria in Platonem sua as Nicolaum valorem pudentem, optimumque civem (Florence: Per Lurentium Francici de Venetiis, 1496), and in the University of Prague MS RVI Ef11 (c. 1493). "Hinc revertitur iterum ad vires anime dividendas, et rationem quidem aurigam vocat, geminos vero appetitus equos geminos: appetitum rationalem equum bonum, appetitum irrationalem equum malum; sed in hoc genere appetitum vergentem ad iracundiam minus malum, declinantem vero ad concupiscentiam magis malum" (p. 79). Ficino returns to contrast later to emphasize it. See p. 99.

41. Ficino, Phaedran Charioteer, p. 146: "Dicitur autem aurigatio nostra difficilis, quoniam motus quidem superioris equi ad intelligibilia, inferioris autem ad sensibilia vergit, ad genituramque declinat" ( see p. 147 for the English translation). See also the similar sentiment - with Venus and Saturn in place of the contrary horses - in Ficino, Three Books on Life, pp. 214-6.

42. Ficino, Phaedran Charioteer, p. 190: “...tanquam generosus libidinem quidem amputet, amoris autem sublimitatem retinens, efficiat amicitiam" (see p. 191 for the English translation). See also Marsilio Ficino, The Philebus Commentary, ed. and trans. Michael J. B. Allen (Tempe: Arizona Center for Medieval and Renaissance Studies, 2000), p. 139: "Anima cum primum ea foecunditate referta est per conversionem ad supera intelligibilem in se ipsa procreat pulchritudinem." On the other hand, the concept of the two Venuses seems to suggest that the love of earthly Venus threatens the transcendent love of the heavenly Venus. See p. 137.

43. Ficino, De amore, “...desiderium hoc perfectionis proprie propagande cunctis ingenitum, latentum et implicatam cuiusque fecunditatem explicat...." Elsewhere, Ficino recognizes that narcissism is a powerful support for love. See for example Letters, vol 1, pp. 144-5; vol. 2, p. 56.

44. Kristeller, Philosophy, pp. 136-8. For Ficino, procreation was a practical matter as well in that in ensured the continuation of humanity. Consult Philebus Commentary, p. 245: "...videlicet per Venerem ad salutem speciei...."

45. Ficino, De amore, "Ita pregnans hominum corpus est, ut Plato vult, pregnans et animus, et ambo amoris incitamentis stimulantur ad partum....Quoniam vero genitalis illa vis anime, utpote cognitionis expers, sexum nullum habet discrimen, natura tamen sua totiens incitatur ad generandum, quotiens formosum corpus aliquod iudicamus, contingit 
plerumque ut qui cum masculis conversantur, quo genitalis parties stimulos sedent illis se misceant." For a concise account of the differences between Aristotelian and Galenic schools on procreation, see Mary Lindemann, Medicine and Society in Early Modern Europe (Cambridge: Cambridge University Press, 1999), pp. 12-4, 67-70.

46. P. 230: "Oportebat autem animadvertere partis illius incitamenta non irritum hac iacture opus, sed serendi et procreandi officium affectare atque a masculis ad feminas eam traducere."

47. The Italian text added, "It is not pleasant to do..." (that is, talk about sexual matters, especially involving two men). See Marsilio Ficino, Marsilio Ficino's Commentary on Plato's Symposium, trans. and intro. Sears Reynolds Jayne (Columbia, MO.: University of Missouri, 1944), p. 208 and note.

48. P. 158. On Ficino's conception of "daemons," see D. P. Walker, Spiritual and Demonic Magic: From Ficino to Campanella (London: The Warburg Institute,1958), pp. 45-53; Allen, Platonism, pp. 9-31.

49. P. 163. Balance and reciprocity were central to humoral theory, which dominated contemporary medical opinion. See for instance Michele Savonarola, Libro della natura et virtu delle cose, che nutriscono, \& delle cose non natural (Venice: Domenico \& Gio. Battista Guerra, 1576), which includes long-standing beliefs about balancing the humors.

50. P. 220: "communis attractio." Also on p. 220: "attractio rei unius ab alia." There is also the use of "mutuus" frequently. See esp. 155-6.

51. P. 153: "Illud quoque evenire sepenumero solet ut se in amati personam quisque transferre cupiat. Nec immerito, deus namque pro homine fieri cupit atque conatur."

52. P. 156: "Quotiens duo aliqui mutua se benivolentia complectuntur, iste in illo, ille in isto vivit." See also the discussion of superior/inferior relations on p. 160.

53. P. 174: The gender politics of coitus in Ficino's day owed a great deal to ancient ideas, many of which are discussed in Thomas Laqueur, Making Sex: Body and Gender from the Greeks to Freud (Cambridge, MA.: Harvard University Press, 1992), pp. 25-62.

54. Paul O. Kristeller, ed. Supplementum Ficinianum, 2 vols. (Florence: Leonis S. Olschki, 1937), vol. 1, p. 90. “...tutti quasi amiamo male, et quanto più amiamo tanto peggio amiamo....Questo mostruoso errore guai a noi c'aviene perchè temerariamente entriamo prima in questo faticoso viaggio d'amore, che impariamo el termine suo et modo di camminare et e pericolosi passi del cammino, et però quanto più andiamo, tanto più oimè miseri a nostro grande danno erriamo."

55. Rocke, Forbidden Friendships, p. 94.

56. The first edition was Pietro Bembo, Gli Asolani di messer Pietro Bembo (Venice: Aldo Romano,1505). The edition consulted and cited hereafter was Pietro Bembo, Prose $e$ rime di Pietro Bembo, ed. Carlo Dionisotti $2^{\text {nd }}$ ed. (Turin: Unione Tipografico-Editrice, 1966); p. 328: “Amore valorose donne, non figliuolo di Venere,... né di Marte o di Mercurio o di Volcano medesimamente o d'altro Idio, ma da soverchia lascivia e da pigro ozio degli uomini, oscurissimi e vilissimi genitori, nelle nostre menti procreato, nasce da primo quasi parto di malizia e di vizio." 
57. P. 332: "E perciò che non è altro l'amaro che io dissi, che il tormento et dolor dell'animo...."

58. Pp. 350-1: “...che l'uom non possegga quello che egli disidera, tante volte egli dà luogo in sé alle passioni...perciò che non può l'uom fruir compiutamente cose, che non sia tutta in lui; con ciò sia cosa che le strane sempre sotto l'arbitrio della fortuna stiano...."

59. P. 375: “...nelle brutture terrene i meniera, che spesse volte disaventurosamente v'affoghiamo." The jealousy discussion is on p. 342.

60. Pp. 352-3: “...disordinati pericoli e a mille miserie ci conduce. Questo sospinge il fratello a cercare dalla male amata sorella gli abominevoli abbracciamenti, la matrigna del figliastro, e alcuna volta, il che pure a dirlo m'è grave, il padre medesimo dalla verginetta figliuola: cose più tosto mostruose che fiere.... [N]on per tanto ce ne sappiam ritenere $\mathrm{o}$, se pure alcuna volta ce ne riteniamo, da capo, come quelli che il male abbiam dentro, al vomito con maggior violenza di stomaco ritorniamo."

61. P. 402: "Perché se alcuno ama la sua donna, egli cerca la sua metà. Noi non siamo interi... se soli maschi, o sole femine ci siamo." The language of course echoes the Aristophanes speech on the origins of love. See Symposium 189c-191d. The discussion in De amore is on pp. 167-77 (Oratio quarta).

62. P. 408: “...affetto alcuno naturale si mescoli nelle perturbazioni."

63. P. 415: "quegli appetiti così trabocchevoli." See pp. 397-8 for the distant lover; pp. 426-7 for the senses.

64. P. 420: "Perciò che se Amore due separati corpi non congiugnesse, atta a generar lor simili, non ci se ne generarebbe, né ce ne nascerebbe mai alcuna."

65. P. 421: “...il dolce giogo della moglie e del marito n'andarono... con le vergognosa onestà."

66. Bette Talvacchia, Taking Positions: On the Erotic in Renaissance Culture (Princeton: Princeton University Press, 1999), p. 107.

67. P. 427: "tra per questo e per la calda stagione d'un drappo schietto e sottilissimo vestita, la forma di due poppelline tonde e sode [saldo] e crudette dimonstrava per la consenziente vesta."

68. For a brief account of the publication history, see Pietro Bembo's Gli Asolani, trans. Rudolf B. Gottfried, Indiana University Publications Humanities Series No. 31, (Bloomington, IN: Indiana University Press, 1954), pp. xiii-xv. Later editions expanded this section considerably.

69. P. 458: "moderatrice de' soverchievoli disii."

70. P. 491: "il buono amore disio solamente di bellezza." See pp. 464-5 for the discussion of procreation.

71. Pp. 488-9. On controlling desire, see 490: “Ché miglior parte della vita nostra è per certo quella, figliuolo, in cui la parte di noi migliore, che è l'animo, dal servaggio degli appetiti liberata, regge la men buona temperatamente, che è il corpo, e la ragione guido il senso...." 
72. Symphorien Champier, Le Livre de vraye amour, intro. and ed. James B. Wadsworth ('s-Gravenhage: Mouton, 1962), p. 12. While it is not clear how extensive Champier's knowledge of Greek classics was, he did quote Plato's Symposium, probably known from Ficino's Latin translation, in Nef des Princes (Lyon: G. Balsarin, 1502), fol. 48. Champier's work suggests that he did not know Greek.

73. All citations from the main text are from Symphorien Champier, Nef des dames vertueuses composees par maistre Simphorien Campier Docteur en medicine contenant quatre livres. Le premier est intitule la fleur des dames. Le Seconde est du regime de marriage. Le tiers est des propheties des sibilles. Et le quart est le livre de vraye amour nouvellement imprimez a Paris pour Jehan de la Garde (Paris: Jehan de la Garde, 1515): "La chasteté du Susanne, la puritee de Lucresse...la vaillance de la royne Semiramie."

74. Sig j iv (r): “...les biens du corps dune femme sont beaulte et grandeur. Et les biens de lame sont temperance amour de opation;" and unpaginated: "Lune est la voye de vice plaisante a sensualite humains desplaisante a dieu laquel le alaparfin conduit a perdition."

75. Wadsworth reproduces the dedicatory letter in his edition, and I cite it from his text as the 1503 first edition is exceedingly rare. The text of Nef des Dames otherwise utilized is the 1515 edition, which was more widely circulated. Despite that the later edition lacked the dedicatory letter, I consulted it because it was the version that circulated more widely.

76. Champier, Vraye amour, p. 43: “...in animi trutina in quem potissimum amorem meum converterem."

77. Champier, Vraye amour, p. 45: "Etenim telis trifariam utor; nam in divinum modo amorem moveo, modo ad humanum, que duo honesta sunt amoris genera omnique petulantia denudata, demum in eum quem ferinum philosophi vocant qui et petulans est et lascivus concutio."

78. Champier, Vraye amour, p. 47: "Vis quidam generandi genderande pulchritudinis, intelligendi vero potentia contemplande illius habet desiderium."

79. Sig. q ii (r): “Amour n'est aultre chose que desir de chose belle et honneste....Et amour n'est que desir de beaulté." Champier draws heavily on three of Ficino's chapters from the De amore: Oration 1:4 (De utilitate amoris, pp. 141-4); 2:3 (Pulchritudo est splendor divine bonitatis, pp. 147-9); and 2: 8 (Exhortatio ad amorem, De amore simplici ac mutuo, pp. 155-8).

80. Sig. q ii (r): "L'enraigement et folie de concupiscence charnelle et venerée conduit à prodigalité, intemperance, infameté, et à choses villes."

81. Sig. q ii (v): "Cest appetit charnel et venerée ne se peult dire amour."

82. Giovanni Boccaccio, The Decameron, trans. and intro. G. H. McWilliam, $2^{\text {nd }}$ ed. (London, New York: Penguin Books, 1995). For the Cymon/Iphegenia story (Day V, Story1), see pp. 367-78. For the Titus and Gisippus (Day X, Story 8), see pp. 745-64. Champier's ancient sources, in addition to Plato and Aristotle, included Herodotus, Aulus Gellius, and Ovid. See sig. q ii (v)- sig. q iii (r) for some of these references; Champier was evidently conversant with Italian humanist sources. 
83. Sig. q iii (v)-sig. q iv (r): "insensé et fol de nature et avoit la voix rude et laide;" "les meurs de beste plus que d'homme;" "une belle fille et jeune, plaine de beaulté;" "homme civil."

84. Sig. $\mathrm{r}$ iii (v): “...il aimoit mieulx perdre sa femme que son amy, car facillement on peult trouver une aultre femme mais non point ung amy."

85. Laurens Bouchel, La Bibliothèque ou thresor du droict françois, auquel sont traictees les matieres Civiles, Criminelles, \& Beneficiales, tant reglées par les Ordonnances, \& Coustumes de France, que decidées par Arrests des Cours Souveraines, 3 vols. (Paris: Jean Girin et Barthelemy Riviere, 1671), vol. 3, pp. 368-9: "Inceste est, avoir compagnie charnelle avec son lignage, parenté, ou son affinité; Qui a affaire avec sa mere, niece, ou fille, il est à punir plus que l'adultere, par mort publique, scandaleuse et exemplaire: pour estre exemple aux autres de se garder de semblable offense." The first volume appeared in 1639 , but the collection codifies case law and earlier definitions.

86. Sig. rv (v): "concupiscence charnelle est une espece de anragement et fureur."

87. "O Dames, veillez estre amoureuses de vraye amour et nayant peur de ce que dit Platon quant il dit que celluy qui ayme est mort en soy mesmes et a vit en aultruy, car il vit en lachose quil ayme....O hommes soyes viriles. O dames soyes vertueuses prudentes et pudiques." This concluding section is unpaginated.

88. Among the more helpful accounts of the gendered meanings of blasons is Nancy J. Vickers, "Members Only: Marot's Anatomical Blazons," David Hillman and Carla Mazzio, ed. The Body in Parts: Fantasies of Corporeality in Early Modern Europe (London and New York: Routledge, 1997), pp. 3-21. For the English context, see especially Jonathan Sawday, Body Emblazoned: Dissection and the Human Body in Renaissance Culture (London and New York: Routledge, 1995).

89. On the ambiguities about marriage, see for instance Guido Ruggiero, The Boundaries of Eros: Sex Crime and Sexuality in Renaissance Venice (New York and Oxford: Oxford University Press, 1985), pp. 16-69; for England, see Martin Ingram, Church Courts, Sex and Marriage in England, 1570-1640 (Cambridge: Cambridge University Press, 1987).

90. Susan J. Wiseman, “'Tis Pity She's a Whore: Representing the Incestuous Body,” Renaissance Bodies: The Human Figure in English Culture c. 1540-1660, ed. Lucy Gent and Nigel Llewellyn (London: Reaktion Books, 1990), pp. 180-97. Wiseman reads this moment as one of recognition on Annabella's part (p. 188). If so, Annabella's willful bad desire is even more striking.

91. Lisa Jardine, "Boy Actors, Female Roles, and Elizabethan Eroticism," Staging the Renaissance: Reinterpretations of Elizabethan and Jacobean Drama, ed. David Scott Kasten and Peter Stallybrass (New York and London: Routledge, 1991), pp. 57-67. See p. 59. 